\title{
The commognitive perspective of teaching skills of prospective mathematics teachers in microteaching subjects
}

\author{
Moh Zayyadi ${ }^{1}$, Toto Nusantara ${ }^{2}$, Harfin Lanya ${ }^{1}$ \\ ${ }^{1}$ Mathematics Education Department, University of Madura, East Java, Indonesia \\ ${ }^{2}$ Mathematics Education Department, State University of Malang, East Java, Indonesia \\ *Correspondence: zayyadi@ unira.ac.id
}

(C) The Author(s) 2022

\begin{abstract}
This study aims to describe the teaching skills of prospective mathematics education teachers in micro-teaching subjects from a commognitive perspective. This type of research is qualitative research. The research subjects consisted of 15 students of the 2015 Mathematics Education Study Program class, which were taking micro-teaching courses. The instrument used in this study was a rubric sheet - an assessment of prospective teachers' teaching skills. Data analysis techniques used are data reduction, data presentation, and conclusion collection. The results showed that: Prospective mathematics education teachers in preliminary activities often use the word usage component, visual mediator, routine and do not use the narrative component. In the core activities of learning mathematics, teacher candidates use four components commognitive, which are the use of words, visual mediators, routine, and narrative. In the selection of mathematics education, teacher candidates only use the word use component. Commognitive provides an overview of mathematical cognitive-communication and content in the learning carried out.
\end{abstract}

Keywords: commognitive; microteaching; teaching skills 


\section{Introduction}

Learning with micro-teaching is still widely practiced by several universities in Indonesia in providing experience and knowledge in the teaching process for prospective teacher students. Microteaching learning is a recorded and practical implementation system that applies during the teaching process under controlled conditions and focuses on teaching skills (Kazu, 1996). In addition, microteaching is believed to consist of controlled elements; microteaching prepares prospective teachers in teaching practices and the teaching profession (Hiebert et al., 2003). Microteaching is a cycle in which prospective teachers plan lessons that focus on specific subjects and present lessons in 10-15 minutes to 10-15 with classmates and instructor and recorded on video (Bilen, 2015). In this study, micro-teaching is meant to control all forms of teaching conducted by prospective teacher students, with students being friends and lecturers as supervisors. Microteaching is expected to prepare prospective teachers in carrying out actual teaching.

Microteaching learning is expected to help prospective teacher students give the experience of being actual teachers in the class to adapt to teaching. Microteaching is thought to provide a transition period for preparing the environment in classroom learning (Kilic, 2010). Microteaching learning can provide benefits in solving problems related to preparing, presenting, and applying lessons (Remesh, 2013). Microteaching assists teachers in developing teaching levels and helps students make critical factor levels of understanding in a short period with greater understanding (Mahmud \& Rawshon, 2013).

One research framework that can provide teacher teaching information in learning mathematics is commognitive. Commognitive is a combination of the words: communication and cognitive. Commognitive is defined as a different type of communication; determined by the object (word use); all types of mediators are made and followed up for communication (visual mediators); a set of level rules followed by ole (routine); the results of the process (narrative) produced in the discourse community. Investigates teaching practices carried out by mathematics teachers in three categories: providing explanations, motivations, and asking questions (Viirman, 2015). They investigated mathematics teacher teaching practices on basic differential material (Tasara, 2017). Investigatprimaryoviding pre-service teacher teaching information in achieving mathematics teaching goals using a commognitive framework (Tuset, 2018). The process of solving middle school students' mathematical problems is based on commognitive (Zayyadi et al., 2019).

Commognitive can impact the professional development of prospective teachers in increasing students' exploratory participation in elementary and secondary schools (Metzuyanim \& Tabach, 2018). In addition, commognitive has also been used to examine teacher discourse about teaching, including teacher professional identity and mathematical discourse (Metzuyanim \& Tabach, 2018).

One way to develop professional teacher candidates in participating in learning interactions is using commognitive. Commognitive as a basis for understanding student teacher candidates in developing teaching skills in the classroom. Commognitive provides more information and understanding for student-teacher candidates to achieve the learning 
objectives. That goal is done through microteaching. With the commognitive framework in learning in microteaching, it is expected to help prospective teacher students provide experience, understanding, and development to become real teachers in the classroom so that they can adapt in learning by using word use, visual mediators, routines, and narratives. Therefore, this research is essential to help prospective teachers become real and professional teachers. This study aimed to describe the teaching skills of prospective mathematics education teachers in micro-teaching courses from a cognitive perspective.

\section{Methods}

The descriptive qualitative was used in this research. This study aims to describe the teaching skills of prospective mathematics education teachers in micro-teaching courses from a cognitive perspective. The subjects of this study were ten students of the 2015 Mathematics Education Study Program, University of Madura. The ten students consisted of five male students and five female students. The material taught in high school mathematics, following the microteaching supervisor's basic competencies. The instrument used is the observation sheet for prospective teachers' teaching skills, as shown in table 1 and the Learning Implementation Plan (RPP). In addition to the observed teaching skills, this observation sheet is also commognitive component in learning. There is a collaborative assessment between the commognitive component and teaching skills in the introduction, core, and closing activities. The data analyzed is video data on the implementation of teaching skills of prospective teachers when carrying out microteaching and lesson plans (RPP) made by prospective teacher students.

The data analysis technique used in this research is data reduction. In this data reduction, the researcher filtered the data to use data that matched the teaching and commognitive skills. At the stage of presenting the data, the researcher presents the data analysis in several forms to make it easier to conclude. The last stage in the data analysis is concluding.

The research analysis conducted was an analysis of the teaching skills of prospective mathematics teachers in micro-teaching subjects. The students' activities in learning this research are described as follows:

Table 1.The students' activities in learning

\begin{tabular}{ll}
\hline No & \multicolumn{1}{c}{ The students' activities in learning } \\
\hline 1 & Preliminary activities \\
& a. Prepare students mentally and physically \\
& b. Apperception and provide motivation \\
& c. Convey learning objectives \\
& d. Convey the scope of the material \\
\hline 2 & Core activities \\
& a. Delivering material, \\
b. Application of the concept of learning materials to life \\
c. Implementing learning strategies \\
d. Using learning media \\
e. Implementing classroom management \\
f. Involving students in learning \\
g. Conducting assessments in learning.
\end{tabular}




\begin{tabular}{ll}
\hline No & \multicolumn{1}{c}{ The students' activities in learning } \\
\hline 3 & Closing activities \\
& $\begin{array}{l}\text { a. Summarizing learning material a } \\
\text { b. }\end{array}$ \\
\hline
\end{tabular}

\section{Results}

The results section contains data exposure and research findings of the commognitive component of prospective teacher students when implementing classroom learning based on content knowledge and pedagogical knowledge.

\section{Preliminary activities}

In the learning activities, students carry out several learning steps to prepare students mentally and physically, as figure 1, apperception and provide motivation, convey learning objectives, and convey the scope of the material. The activity looks like below:

Subject: Assalamu Alaikum Children

Student: Wa'alaikumsalam mother

Subject: How are you today?

Student: Yes Sir

Subject: Have you had lunch?

Student: Not yet

Subject: Before we start the lesson today, it would be better for us to pray first so that the knowledge we gain is useful for us and for others

Student: Yes Sir

Subject: To the class leader to lead the prayer, sister Dinda

Student 1: Before we learn, let us pray first according to each other's beliefs start (Teacher and Students pray)

Student: Finish

Subject: Okay, Mother was absent beforehand, did anyone not attend today? (The teacher checks the presence of students) as Figure 1.

Student: There is sir

Subject: Who

Student: Sofia, it hurts

Subject: What pain?

Student: Mother, I have a fever

Subject: Okay at this meeting we will discuss about the equation of the absolute value of linear variables, does anyone know what is the equation of the linear absolute value of one variable?

Student: Don't know Sir,

Student: The value is always positive, yes and the variable is not one

Subject: Yes, then someone knows again

Student: If there is absolute brackets like that, right?

Student: Okey, Sir

Subject: So the equation of the linear absolute value of one variable is an equation that involves absolute value with a variable that has the highest rank of one. That is called the equation of the linear absolute value of one variable. 
Student: Yes Mom.

Subject: Our first learning goal today is to understand and identify the absolute value equation from the linear form of one variable. The second goal is to solve the problem of the absolute value equation of the linear form of one variable.

Student: Yes

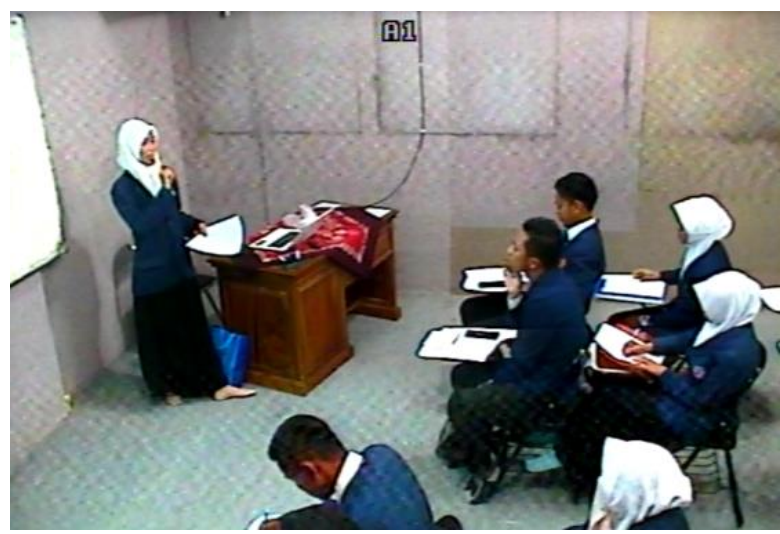

Figure 1. Subject prepares students mentally and physically

The component in preliminary activities is to prepare students mentally and physically; "Before we start the lesson today, it would be better for us to pray first so that the knowledge we gain is useful for us and others," do apperception and provide motivation to convey learning objectives, "Our learning goal today is first to understand and identify the absolute value equation from the linear form of one variable." and deliver the scope of the material "Okay at this meeting we will discuss the equation of absolute linear value one variable, does anyone know what is the linear absolute value equation of one variable?". In the preliminary activities, word use that is done by the subject is with mathematical terms, colloquial words, and other mathematical terms as keywords following the material being taught, and word use is used as a keyword. Initial information is given to students following the material to be taught. According to the statement, the word used in mathematical discourse includes specific words (certain words) (Mosvold, 2016). In addition, word use in this study is used in interpreting mathematical material. It is consistent with the statement that words are commonly used with mathematical meanings (Sfard, 2008).

In general, in the preliminary activity, the subject only uses the word use component. The subject does not use visual mediators, narratives, and routines, so the cognitive component in this activity is incomplete.

\section{Core activities}

In the core activities, students carry out several learning steps such as delivering material, implementing learning strategies, using learning media, implementing classroom management, involving students in learning, as Figure 2, and conducting assessments in learning. The activity looks like below:

Subject: Here the mother uses the STAD learning method. Alright mom will make you into groups here group 1 this is group 2 yes (teacher divides students into 2 groups)

Student: Yes ma'am 
Subject: Mother will give a Student Worksheet to each group, please discuss it with her friends. This is group 1 group 2 (The teacher distributes worksheets to each group) discuss with his friends, circular is also okay.

Subject: Are you done?

Student: Not yet, ma'am (Students continue working on the questions at the worksheets)

Subject: Okay, we will explain the equation of the linear absolute value of one variable, what is absolute value? The absolute value can be called the absolute value of the absolute value of the modulus value and is denoted by a symbol like this (symbol $|\dashv|$ ) which means it is positivated (pointing to the slide that has been displayed on the board).

Student: If the value is negative sir?

Subject: Yes with symbols like this $(\dashv \mid)$ can be positivated for example -2 is equal to 2 in positive

Student: So it's always positive, sir

Subject: Yes, for example $x$ is a real number so if the symbol is like this $|x|$ can be read the absolute value of $x$.

Student: Absolute value $x$

Subject: Yes and the absolute value $(|x|)$ is defined as $x$ if $x \geq 0,-x$ if $x<0$.

Student: Should it be $x$, ma'am? If for example $z$ or otherwise it can't be ma'am?

Subject: Any $a, b, c$ anything, this is just a symbol. $X$ is just a symbol. Alright so that you can understand more directly to the examples, okay? (shows an example on the slide shown)

Example:determine the value of $x$ if one satisfies the following equation $|2 x-1|=$ 7.

First we change the shape of $|2 x-1|$ as in the previous definition, so $|2 x-1| 2 x-1$ if $x \geq 1 / 2-2 x-1$ if $x<1 / 2$ like the previous definition.

Student: Yes sir

Subject: Try to do the problems in the worksheet

Student: What's the number, mom?

Subject: All. (Students work on the questions in the worksheet individually). Yes, then the individual answers are compared with the group and select the correct answer

Student: Yes sir (students compare the answer with their respective groups)

Subject: Come on, Hendri, come forward.

Student: Yes sir, (Each group representative writes the results of their group answers on the blackboard)

Subject: Please present group one. (group representatives present their answers)

Student: Well here for the first problem equation $|6 x-12|=0$

$$
\text { to } \begin{aligned}
6 x-12 & =0 \\
6 x & =12 \\
x & =12 / 6
\end{aligned}
$$

Thus producing $x=2$ that satisfies the equation $|6 x-12|=0$

Subject: Ok from your answer here, I can conclude that you already understand about the equation of the linear absolute value of a variable. Alright mom will give you a quiz (teacher gives quiz questions to students)

Student: Gather now?

Subject: Yes, collect it now. Do what you can. (Students work on quiz questions that have been given) 
Student: Yes sir, have you collected sir?

Subject: Yes collected. I saw the questions from the quiz answers, I was able to give you an appreciation for the best group which group was good (The teacher corrected the quiz results of the students and gave awards) the best group was group one.

Student: Yes.

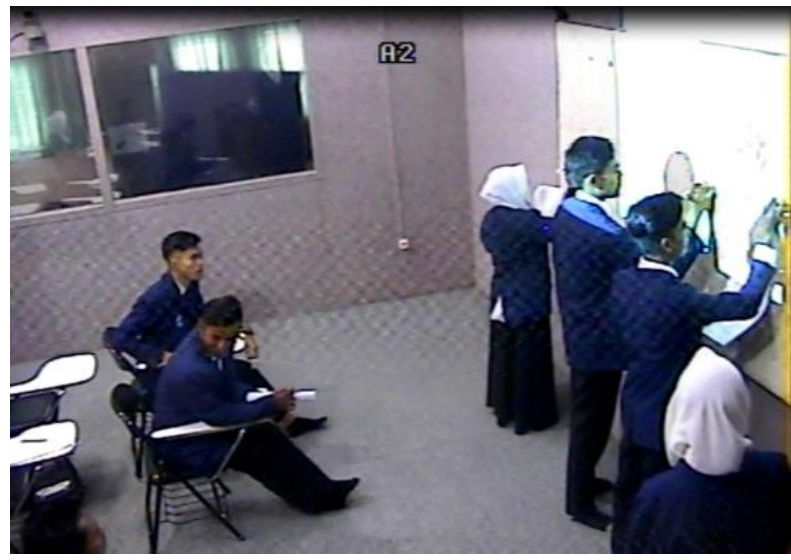

Figure 2. Subject involving students in learning

The use of the word use component in the core learning activities includes conveying material such as "Okay, before we will explain the equation of the linear absolute value of one variable, what is absolute value? Absolute value can be called the absolute value of the modulus and notated with symbols like this (symbol $|\dashv|$ ) which means positive ", applying the learning strategy" Mother uses the STAD learning method. All right, mother will make you into a group here, group 1, group 2 (teacher divides students into two groups), use learning media, and carry out classroom management. "I will give Student Worksheets to each group; please discuss with friends. It is group 1 group 2 (the teacher distributes student worksheets to each group) discuss with his friends, circular also does nothing ", involve students in learning and conduct assessments in learning such as" Mother saw the questions from the quiz answers before the mother can give you an award which group is the best which group is good (the teacher corrects the quiz results of students and gives awards) the best group is group one. " In the core activities, word use is used as a keyword, and initial information is given to students in accordance with the material to be taught. According to Mosvold's statement (2016), the word used in mathematical discourse includes specific words (certain words). In addition, word use is used as a material that must be explained to students (explaining activities). It is consistent with the opinion (Ngin, 2018) that word use is essential in mathematics discourse in this activity because it helps convey meaning to students.

Visual mediators, in this case, are using power points and existing worksheets (the work done in the UK is worksheets) as Figure 3, blackboards, and explanations are student-teacher candidates giving questions. In the context of commognitive subjects, concrete media can be seen and real. It follows the opinion of Sfard (2008), who revealed that this concrete mediator could be seen and seen in plain view. In addition, in his theory, Bruner also believes that conceptual understanding can be improved if students are confronted with different 
representations of a concept on three main types of representations: concrete, iconic, and symbolic (Cabahug, 2012).

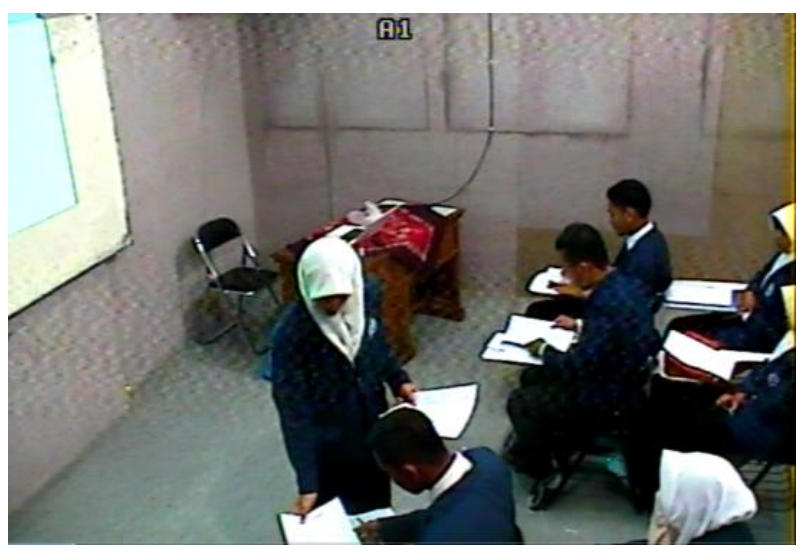

Figure 3. Subject using existing worksheets

The narrative component conducted by students is to use the concept of absolute value. It follows the opinion that the narrative is more to explain the concept of limits to students and students better understand them, including providing scaffolding in explaining the concept and solving problems (Zayyadi et al., 2020, 2021). The routine component that the prospective teacher does include explaining the meaning of the limit and explaining about $|\mathrm{x}|$ "Yes, for example, $\mathrm{x}$ is a real number, so if the symbol is like this $|\mathrm{x}|$ can read the absolute value $\mathrm{x}$. " It is in accordance with the opinion of (Leinhardt, 1990), instructional explanation aims to explain concepts, procedures, events, ideas, and class problems to help students understand, learn and use information in flexible ways. The subject also gave several questions on the sidelines of explaining the material. Consistently, questions can determine the extent of students' understanding (Zayyadi et al. 1., 2019). In addition, the subject did the explanation by giving some rituals and giving questions to students during the learning interaction. The activity is appropriate that routines can be categorized into exploration, deeds, and rituals (Sfard, 2008). Communication frameworks related to types of routines are deeds, rituals, or exploration (Tabach \& Nachlieli, 2016).

\section{Closing activities}

In the closing activity, students carry out several learning steps, such as summarizing learning material and reflecting on learning. The activity looks like below:

Subject: Okay, so that we do not forget the material, we can look back at what is the linear absolute value equation of one variable, maybe someone knows?

Student: Equations involving absolute value with one variable and high rank are one

Subject: Good

Student: The equation of absolute value with one variable is an equation that involves absolute value with one variable having the highest rank of one.

Subject: Good so the linear absolute value equation of one variable is the equation that involves having the highest rank is one. Well, before closing the lesson today, next week we will learn about ranks and sequences

Student: Yes Sir 
Subject: Please learn about ranks and sequences

Student: Yes Sir, ready.

Subject: And maybe that's all you can say, less and more, sorry, wassalamu 'alaikum Wr. Wb.

Student: Wa'alaikumsalam Wr. Wb.

The word used in this activity allows students to conclude their conclusions from learning, ask students to learn the following material, "Please learn about ranks and sequences," and say the closing sentence, "assalamualaikum warahmatullahi wabarakatuh." Routine in this activity is to provide an opportunity to make their conclusions from the learning done, motivate students to learn at home about the material to be studied next meeting, and close learning.

\section{Discussion}

Based on the above research results, the commognitive component of prospective teacher students in learning mathematics used is word use, visual mediator, routine, and narrative. Word use done by the subject is with mathematical terms, colloquial words, and other mathematical terms as keywords in accordance with the material being taught, and word use is used as a keyword, and initial information is given to students by the material to be taught. According to Mosvold's statement (2016), the word used in mathematical discourse includes specific words (certain words). Word use is used such as limit, real number, and other equations (mathematical terms); = (equals), the symbol x (multiplication), etc., are referred to as everyday words. Furthermore, other mathematical terms refer to the numerator, denominator, and others. Visual mediators in learning mathematics are using power points and using existing worksheets as Figure 3, blackboards (each group representative writes the results of their group answers on the blackboard) and explanations are student-teacher candidates giving questions (Ok from your answer here, I can conclude that you already understand about the equation of the linear absolute value of a variable. All right, mom will give you a quiz (teacher gives quiz questions to students) in the context of commognitive subjects using concrete media that can be seen and real. Sfard's (2008) opinion revealed that this concrete mediator could be seen and seen in plain view.

The narrative component conducted by students is to use the concept of absolute value. It follows the opinion that the narrative is more to explain the concept of limits to students and students better understand them, including providing scaffolding in explaining the concept and the process of solving problems (Zayyadi et al., 2020). The routine component that prospective teacher does include explaining the meaning of the limit and explaining about $|\mathrm{x}|$ "Yes, for example, $\mathrm{x}$ is a real number, so if the symbol is like this $|\mathrm{x}|$ can read the absolute value $\mathrm{x}$. "It is in accordance with the opinion of Leinhardt (1990), instructional explanation aims to explain concepts, procedures, events, ideas, and class problems to help students understand, learn and use information in flexible ways. 


\section{Conclusion}

Teaching skills of prospective mathematics education teachers in microteaching subjects in a commognitive perspective are capable of carrying out preliminary activities, core activities and closing activities. Prospective teacher students in this study did not apply the concept of the material conveyed in their daily lives. The commognitive prospective teacher candidates use all the commognitive components such as word use, visual mediator, narrative, and routine.

The use of the word use component in learning activities includes conveying material such as "Okay before we will explain the equation of the linear absolute value of one variable, what is absolute value? Absolute value can be called the absolute value of the absolute value of the modulus and denoted by a symbol like this (symbol $|\dashv|$ ) which means it is positive ", Visual mediator, in this case, is to use a powerpoint and use the existing worksheet (the UK employed is contained in the worksheet), the blackboard and do the explanation is the prospective teacher students give questions. The narrative component conducted by students is to use the concept of absolute value. The routine component that the prospective teacher does includes explaining the meaning of the limit and explaining about $|\mathrm{x}|$ "Yes, for example, $\mathrm{x}$ is a real number, so if the symbol is like this $|x|$ can read the absolute value $x$. " Based on the results of this study, the teaching skills of prospective teacher students can be assessed with commognitive theory. Commognitive describes the skills of prospective teacher students in learning mathematics from all components of the commognitive. Therefore, future research can examine pedagogical prospective teacher students from a commognitive perspective.

\section{Conflicts of Interest}

The authors declare that no conflict of interest regarding the publication of this manuscript. In addition, the ethical issues, including plagiarism, misconduct, data fabrication and/or falsification, double publication and/or submission, and redundancies have been completely by the authors.

\section{References}

Bilen, K. (2015). Effect of micro teaching technique on teacher candidates' beliefs regarding mathematics teaching. Procedia-Social and Behavioral Sciences, 174, 609-616. https://doi.org/10.1016/j.sbspro.2015.01.590

Cabahug, J. A. (2012). The use of Bruner's modes of representations in teaching factoring seconddegree polynomials. International Journal of Education, 1(1), 85-103. https://doi.org/10.7718/iamure.ije.v1i1.102

Hiebert, J., Morris, A. K., \& Glass, B. (2003). Learning to learn to teach: An "experiment"model for teaching and teacher preparation in mathematics. Journal of mathematics teacher education, 6(3),

201-222. https://doi.org/10.1023/A:1025162108648

Kazu, İ. Y. (1996). Endüstriyel mesleki ve teknik ortaöğretim kurumlarındaki işletmelerde meslek eğitimi uygulamalarının değerlendirilmesi (Bursa, Adıyaman, Diyarbakır, Elazı̆̆ ve Malatya illeri örneği) [The Evaluation of cooperative education programs at postsecondary technical and vocational education institutes in Turkey]. 
Kilic, A. (2010). Learner-Centered Micro Teaching in Teacher Education. Online Submission, 3(1), 77-100.

Külahçı, Ş. G. (1994). The experience of the university of Fırat, technical faculty of education in micro education second evaluation. Ë̌itim ve Bilim, 18(2), 36-44.

Leinhardt, G. (1990). Capturing craft knowledge in teaching. Educational researcher, 19(2), 18-25. https://doi.org/10.3102/0013189X019002018

Mahmud, I., \& Rawshon, S. (2013). Micro teaching to improve teaching method: An analysis on students' perspectives. IOSR Journal of Research \& Method in Education (IOSR$J R M E), 1(4)$, 69-76. https://doi.org/10.9790/7388-0146976

Metzuyanim, E. H., \& Tabach, M. (2018). The commognitive theory framework: From theory to implementation. In Movshovitz-Hadar, N. (Ed.), K-12 Mathematics Education in Israel: Issues and Innovations, pp. 343-350. Technion - Israel Institute of Technology. https://doi.org/10.1142/9789813231191_0038

Mosvold, R. (2016). Proceedings of the 24th annual conference of the southern african association for research in mathematics, science and technology education (SAARMSTE), Pretoria South Africa SAARMSTE, 186-195.

Ngin, C. S. (2018). Examining a teacher's use of multiple representations in the teaching of percentages: A commognitive perspective. Mathematics Education Research Group of Australasia.

Remesh, A. (2013). Microteaching, an efficient technique for learning effective teaching. Journal of Research in Medical Sciences, 18(2), 158-163. https://www.ncbi.nlm.nih.gov/pmc/articles/PMC3724377/

Sfard, A. (2008). Thinking as communicating: Human development, the growth of discourses, and mathematizing. Cambridge University Press. https://doi.org/10.1017/CBO9780511499944

Tabach, M., \& Nachlieli, T. (2016). Communicational perspectives on learning and teaching mathematics: Prologue. Educational Studies in Mathematics,91(3), 299-306. https://doi.org/10.1007/s10649-015-9638-7

Tasara, I. (2017). Commognitive analysis of a teacher's mathematical discourse on the derivative. Proceedings of the British Society for Research into Learning Mathematics, 37.

Tuset, G. A. (2018). A commognitive lens to study pre-service teachers' teaching in the context of achieving a goal of ambitious mathematics teaching. In Proceeding, Congress of the European Society for Research in Mathematics Education.

Viirman, O. (2015). Explanation, motivation and question posing routines in university mathematics teachers' pedagogical discourse: A commognitive analysis. International Journal of Mathematical Education in Science and Technology, 46(8), 1165-1181. https://doi.org/10.1080/0020739X.2015.1034206

Zayyadi, M., Nusantara, T., Hidayanto, E., Sulandra, I. M., \& Asari, A. R. (2019). Exploring prospective student teacher's question on mathematics teaching practice. JOTSE, 9(2), 228-237. https://doi.org/10.3926/jotse.465

Zayyadi, M., Nusantara, T., Subanji, S., Hidayanto, E., \& Sulandra, I. M. (2019). A commognitive framework: The process of solving mathematical problems of middle school students. International Journal of Learning, Teaching and Educational Research, 18(2), 89-102. https://doi.org/10.26803/ijlter.18.2.7

Zayyadi, M., Nusantara, T., Hidayanto, E., Sulandra, I., Mand, \& Sa'dijah, C. (2020).Content and pedagogical knowledge of prospective teachers in mathematics learning: commognitive framework. Journal for the Education of Gifted Young Scientists, 8(1), 515-532. https://doi.org/10.17478/jegys.642131 
Supardi, L., Zayyadi, M., Lanya, H., Hasanah, S. I., \& Hidayati, S. N. (2021). Commognitive analysis of students' errors in solving high order thinking skills problems. Turkish Journal of Computer and Mathematics Education, 12(6), 950-961. https://doi.org/10.17762/turcomat.v12i6.2373 